\title{
Identification and Characterization of Salmonella Species Isolated from Broiler Chickens
}

\author{
Walid H. Hassan ${ }^{1}$ - Hala S. Hassan ${ }^{1}$ - Wafaa M.M Hassan² • Salama A.S. Shany ${ }^{3}$. \\ Ghada S.I. Osman ${ }^{*}$
}

Received: 04 August 2021 I Accepted: 24 August 2021 I Published online: 28 August 2021

\footnotetext{
${ }^{1}$ Department of Bacteriology, Mycology and Immunology, Faculty of Veterinary Medicine, Beni-Suef University, BeniSuef 62511, Egypt.

${ }^{2}$ Chef Researcher of Microbiology, Reference Lab. of Quality Control on Poultry Production-Animal Health Research Institute (AHRI).

${ }^{3}$ Department of Poultry Diseases, Faculty of Veterinary Medicine, BeniSuef University, Beni-Suef 62511, Egypt.

${ }^{4}$ Department of Bacteriology, Animal Health Research Institute, Beni-Suef Laboratory, Agricultural Research Center, Egypt.
}

\section{Correspondence}

Ghada S.I. Osman", Department of Bacteriology, Animal Health Research Institute, Beni-Suef Laboratory, Agricultural Research Center, Egypt. Email: dr.ghadasayed2020@yahoo.com

\begin{abstract}
Salmonellosis is one of the most important problems facing poultry industry and a critical food safety hazard. In the present study the prevalence of avian Salmonellosis was studied in different farms of broiler chickens in Beni Suef Governorate, Egypt during the period from January to April 2020. A total of 140 samples were collected from slaughtered diseased or freshly dead broiler chickens aged from one to 35 days. Bacteriological examination revealed that $7.14 \%$ of the samples were Salmonella positive. Serotyping of Salmonella isolates showed that S. kentucky, S. blegdam and S. virchow were recognized at rates of $40 \%$, $30 \%$ and $30 \%$, respectively. Antimicrobial susceptibility test revealed that all salmonella isolates were multidrug resistant (MDR). All isolates were resistant to oxytetracycline $(100 \%)$ while $90 \%$ were resistant to amoxicillin-clavulanic acid, cefotaxime, sulfamethoxazole- trimethoprim and norofloxacin. On the other hand, $80 \%$ of isolates were sensitive to fosfomycin and nitrofurantoin. Results of screening of some MDR isolates by multiplex PCR for detection of some virulence genes showed that all the tested isolates (100\%) had invA, stn, spvC genes meanwhile pefA was not detected in any isolate.

\section{Keywords}

Multidrug resistance, Salmonella, invA, stn, spvC
\end{abstract}

\section{Introduction}

Salmonellosis is an important bacterial disease usually infects poultry flocks. It is caused by a wide variety of Salmonella species (Haider et al. 2004). It represents a critical food safety hazard (VinuezaBurgos et al. 2019). Also Salmonella is one of the most important zoonotic foodborne pathogens (WHO 2016). Salmonellae infections in poultry can be grouped into two categories; the first includes two non-motile serotypes, S. pullorum and S. gallinarum, that causes pullorum disease and fowl typhoid, respectively (Barrow and Neto 2011). The second includes infections with the numerous motile Salmonella serotypes referred collectively as paratyphoid salmonellae. Although infections of poultry with Salmonella enterica serovars are very common, they seldom cause acute systemic disease except in highly susceptible young birds subjected to stress conditions (Gast et al. 2003). Outbreaks of human salmonellosis are associated with the 
consumption of poultry products contaminated with $S$. enteritidis and $S$. typhimurium (Vose et al. 2011).

Although antimicrobial agents are important tools to treat clinically diseased birds and to maintain the healthy and productivity of birds, the misuse of antimicrobials as well as their prophylactic application in poultry industry is considered the cause of drug resistance (Phillips et al. 2004). Resistance of salmonellae to antimicrobials is considered a serious problem worldwide having a very important public health concern. The emergence and spread of these antimicrobial resistances is a complicated problem caused by many interconnected factors (Radwan et al. 2020). In-vitro antimicrobial susceptibility testing of pathogens provides valuable guidance to the veterinarian in the selection of appropriate antimicrobial agent (Radwan et al. 2016). Moreover, it can be used in detection of MDR isolates. Surveillance data showed an obvious increase in salmonellae antimicrobial resistance in the recent days than the past (Su et al. 2004).

There is a strong correlation between the existence of several virulence genes and the pathogenicity of salmonellae (Radwan et al. 2016). The majority of the salmonella isolates from human and food origin harbored the invA, stn, sopB and $s o p \mathrm{E} 1$ virulence genes (Zou et al. 2012).

This study aimed to investigate the antimicrobial resistance and molecular characterization of virulence-associated genes of pathogenic salmonellae isolated from broiler chickens.

\section{Material and Methods}

\subsection{Sample collection}

A total of 140 samples were collected aseptically from broiler chickens aged from one to 35 days collected from Beni Suef Governorate, Egypt during the period from January up to April 2020. These chickens were suffering from respiratory manifestations and/or gastrointestinal problems. Swabs from heart, lung, liver, and yolk sac showed gross lesions were used for bacteriological examination.

\subsection{Isolation and identification of salmonella species}

The collected samples were inoculated under aseptic condition into buffered peptone water (BPW) and incubated aerobically at $37^{\circ} \mathrm{C}$ for 24 hours then inoculated into Rappaport-Vassiliadis (RV) broth and incubated aerobically at $41^{\circ} \mathrm{C}$ for 24 hours. A loopful from the culture media was streaked onto MacConkey's agar and xylose lysine deoxycholate (XLD) agar media, and incubated aerobically at $37^{\circ} \mathrm{C}$ for $24 \mathrm{~h}$. Suspected pale colonies on MacConkey's agar and red with black centers on XLD agar were subjected to further tests for identification. These isolates were identified as Salmonella species based on their colony morphology and biochemical tests according to the schemes described by Collee et al. (1996) and Quinn et al. (2002).

\subsection{Serological identification of Salmonella spp.}

Salmonella serotyping was carried out using slide agglutination test using salmonella antisera to detect the somatic $(\mathrm{O})$ and flagellar $(\mathrm{H})$ antigens according to white Kauffmann-Leminor scheme as described by Grimont and Weill (2007).

\subsection{Antibacterial sensitivity testing}

Disk diffusion technique was carried out in concordance to CLSI (2018). All salmonella isolates were tested for their susceptibility to 9 different antimicrobial discs (Himedia, Turkey) represented different antimicrobial classes of veterinary concern including amoxicillin/clavulanic acid $(30 \mu \mathrm{g})$, cefotaxime $(30 \mu \mathrm{g})$, doxycycline $(30 \mu \mathrm{g})$, fosfomycin $(200 \mu \mathrm{g})$, gentamicin $(10 \mu \mathrm{g})$, nitrofurantoin $(300 \mu \mathrm{g})$, norofloxacin $(10 \mu \mathrm{g})$, oxytetracycline $(30 \mu \mathrm{g})$ and sulfamethoxazole-trimethoprim $(25 \mu \mathrm{g})$, Resistance to three/or more antimicrobials of different groups was considered as multidrug resistance (MDR) according to Magiorakos et al. (2012).

\subsection{Polymerase chain reaction (PCR) for Salmonella isolates}

PCR was applied on 5 MDR salmonella isolates for detection of 4 virulence genes (pefA, stn, invA, $s p v \mathrm{C}$ ). DNA extraction was performed using QIAamp DNA mini kit according to the manufacturer's instruction. Primers sequences and amplified products for the targeted genes for salmonella isolates were illustrated in Table (1). Temperature and time conditions of the primers during PCR were shown in Table (2) according to Emerald Amp GT PCR master-mix Takara) kit. 
Table 1. Primers of virulence genes used in PCR.

\begin{tabular}{|c|c|c|c|c|}
\hline Target gene & Primers direction & Primers sequences & Amplified segment & Reference \\
\hline \multirow{2}{*}{ pefA } & $\mathbf{F}$ & TGT TTC CGG GCT TGT GCT & \multirow{2}{*}{700 pb } & \multirow{4}{*}{$\begin{array}{l}\text { Murugkar et al. } \\
\qquad(2003)\end{array}$} \\
\hline & $\mathbf{R}$ & CAG GGC ATT TGC TGA TTC TTC C & & \\
\hline \multirow{2}{*}{ stn } & $\mathbf{F}$ & TTG TGT CGC TAT CAC TGG CAA CC & \multirow{2}{*}{$617 \mathrm{pb}$} & \\
\hline & $\mathbf{R}$ & ATT CGT AAC CCG CTC TCG TCC & & \\
\hline \multirow{2}{*}{ invA } & $\mathbf{F}$ & GTG AAA TTA TCG CCA CGT TCG GGC AA & \multirow{2}{*}{$284 \mathrm{pb}$} & \multirow{2}{*}{$\begin{array}{c}\text { Oliveira et al. } \\
\text { (2003) }\end{array}$} \\
\hline & $\mathbf{R}$ & TCA TCG CAC CGT CAA AGG AAC C & & \\
\hline \multirow{2}{*}{ spvC } & $\mathbf{F}$ & ACC AGA GAC ATT GCC TTC C & \multirow{2}{*}{$467 \mathrm{pb}$} & \multirow{2}{*}{$\begin{array}{l}\text { Huehn et al. } \\
\qquad(2010)\end{array}$} \\
\hline & $\mathbf{R}$ & TTC TGA TCG CCG CTA TTC G & & \\
\hline
\end{tabular}

Table 2. Cycling conditions of the different primers during PCR

\begin{tabular}{|c|c|c|c|c|c|c|}
\hline Gene & $\begin{array}{c}\text { Primary } \\
\text { denaturation }\end{array}$ & $\begin{array}{c}\text { Secondary } \\
\text { denaturation }\end{array}$ & Annealing & Extension & cycles No. & Final extension \\
\hline \multirow{2}{*}{ pefA } & $94^{\circ} \mathrm{C}$ & $94^{\circ} \mathrm{C}$ & $55^{\circ} \mathrm{C}$ & $72^{\circ} \mathrm{C}$ & \multirow{2}{*}{35} & $72^{\circ} \mathrm{C}$ \\
\hline & $5 \mathrm{~min}$. & $30 \mathrm{sec}$. & $40 \mathrm{sec}$ & $45 \mathrm{sec}$. & & $10 \mathrm{~min}$. \\
\hline \multirow{2}{*}{ stn } & $94^{\circ} \mathrm{C}$ & $94^{\circ} \mathrm{C}$ & $59^{\circ} \mathrm{C}$ & $72^{\circ} \mathrm{C}$ & \multirow{2}{*}{35} & $72^{\circ} \mathrm{C}$ \\
\hline & $5 \mathrm{~min}$. & $30 \mathrm{sec}$. & $40 \mathrm{sec}$ & $45 \mathrm{sec}$ & & $10 \mathrm{~min}$. \\
\hline \multirow{2}{*}{ invA } & $94^{\circ} \mathrm{C}$ & $94^{\circ} \mathrm{C}$ & $55^{\circ} \mathrm{C}$ & $72^{\circ} \mathrm{C}$ & \multirow{2}{*}{35} & $72^{\circ} \mathrm{C}$ \\
\hline & $5 \mathrm{~min}$. & $30 \mathrm{sec}$. & $30 \mathrm{sec}$ & $30 \mathrm{sec}$ & & $7 \mathrm{~min}$. \\
\hline \multirow{2}{*}{ spvC } & $94^{\circ} \mathrm{C}$ & $94^{\circ} \mathrm{C}$ & $55^{\circ} \mathrm{C}$ & $72^{\circ} \mathrm{C}$ & \multirow{2}{*}{35} & $72^{\circ} \mathrm{C}$ \\
\hline & $5 \mathrm{~min}$. & $30 \mathrm{sec}$. & $40 \mathrm{sec}$ & $45 \mathrm{sec}$. & & $10 \mathrm{~min}$. \\
\hline
\end{tabular}

\section{Results}

\subsection{Prevalence of salmonella in the} examined broiler chickens

Out of 140 broiler chicken samples, 10 salmonella isolates were recovered with a prevalence rate of $7.14 \%$.

\subsection{Serotyping of Salmonella isolates.}

Results of serotyping of 10 Salmonella isolates were represented in table (3). Out of 10 Salmonella enterica isolates, 3 serotypes were identified. Salmonella kentucky was the most prevalent serotype; represented as 4 isolates (40\%) followed by Salmonella blegdam and Salmonella virchow; 3 isolates (30\% for each).

Table 3. Serotypes and antigenic structure of Salmonellae recovered from broiler chickens.

\begin{tabular}{|c|c|c|c|c|c|}
\hline \multirow{2}{*}{ Serotypes } & \multirow{2}{*}{ No. } & \multirow{2}{*}{$\%$} & \multirow{2}{*}{ Serogroup } & \multicolumn{2}{|c|}{ Antigenic structure } \\
\hline & & & & 0 & H (H1:H2) \\
\hline Salmonella kentucky & 4 & $40 \%$ & C1 & 8,20 & $i: z 6$ \\
\hline Salmonella blegdam & 3 & $30 \%$ & $\mathbf{H}$ & 6,8 & $g, m, q:-$ \\
\hline Salmonella virchow & 3 & $30 \%$ & C1 & $6,7,14$ & $r: I, 2$ \\
\hline Total No. of isolates & 10 & 100 & & & \\
\hline
\end{tabular}

$\%$ : was calculated according to the total number (No.) of isolates $(n=10)$.

\subsection{Antimicrobial susceptibility testing}

The results of in-vitro susceptibility testing (Table 4) showed that salmonella isolates were completely resistant to oxytetracycline (100\%). A high percentage of isolates were resistant to amoxicillincalvulanic acid, cefotaxime, sulfamethoxazoletrimethoprime and norofloxacin ( $90 \%$ for each) as well as doxycycline (80\%) and gentamicin (50\%). On the other hand, a high percentage of isolates were sensitive to fosfomycin and nitrofurantoin ( $80 \%$ for each). All isolates were MDR (100\%). The average MDR index (MDRI) for all Salmonella isolates was 0.677 . 
Table 4. Antimicrobial susceptibility profile of Salmonella isolates.

\begin{tabular}{|c|c|c|c|c|c|c|c|}
\hline \multirow{2}{*}{ Name of the antibiotics } & \multirow{2}{*}{ Con. $\mu \mathrm{g}$} & \multicolumn{2}{|c|}{ Susceptible } & \multicolumn{2}{|c|}{ Intermediate } & \multicolumn{2}{|c|}{ Resistant } \\
\hline & & No. & $\%$ & No. & $\%$ & No. & $\%$ \\
\hline Amoxicillin-clavulenic acid & $20-10$ & 0 & 0 & 1 & 10 & 9 & 90 \\
\hline Cefotaxime & 30 & 0 & 0 & 1 & 10 & 9 & 90 \\
\hline Doxycycline & 30 & 1 & 10 & 1 & 10 & 8 & 80 \\
\hline Fosfomycin & 200 & 8 & 80 & 0 & 0 & 2 & 20 \\
\hline Gentamicin & 10 & 3 & 30 & 2 & 20 & 5 & 50 \\
\hline Nitrofurantoin & 300 & 8 & 80 & 1 & 10 & 1 & 10 \\
\hline Norofloxacin & 10 & 1 & 10 & 0 & 0 & 9 & 90 \\
\hline Oxytetracycline & 30 & 9 & 0 & 0 & 0 & 1 & 10 \\
\hline $\begin{array}{l}\text { Sulfamethoxazole- } \\
\text { trimethoprim }\end{array}$ & $1.25 / 23.75$ & 1 & 10 & 0 & 0 & 9 & 90 \\
\hline
\end{tabular}

\subsection{PCR for detection of some virulence associated genes.}

The results of PCR illustrated in Table (5) and Figs. (100\%) harbored invA, stn and $s p v$ C genes meanwhile $(1,2)$ revealed that all the tested salmonella isolates no isolates harbored pefA gene.

Table (5). Prevalence of virulence-associated genes in the examined Salmonella isolates.

\begin{tabular}{|c|c|c|c|}
\hline \multirow{2}{*}{ The tested Gene } & \multirow{2}{*}{ No. of tested isolates } & \multicolumn{2}{|c|}{ Positive } \\
\hline & & No. & $\%$ \\
\hline invA & \multirow{4}{*}{5} & 5 & 100 \\
\hline pefA & & 0 & 0 \\
\hline stn & & 5 & 100 \\
\hline SpvC & & 5 & 100 \\
\hline
\end{tabular}

\%: was calculated according to the number (No.) of the tested isolates $(n=5)$.

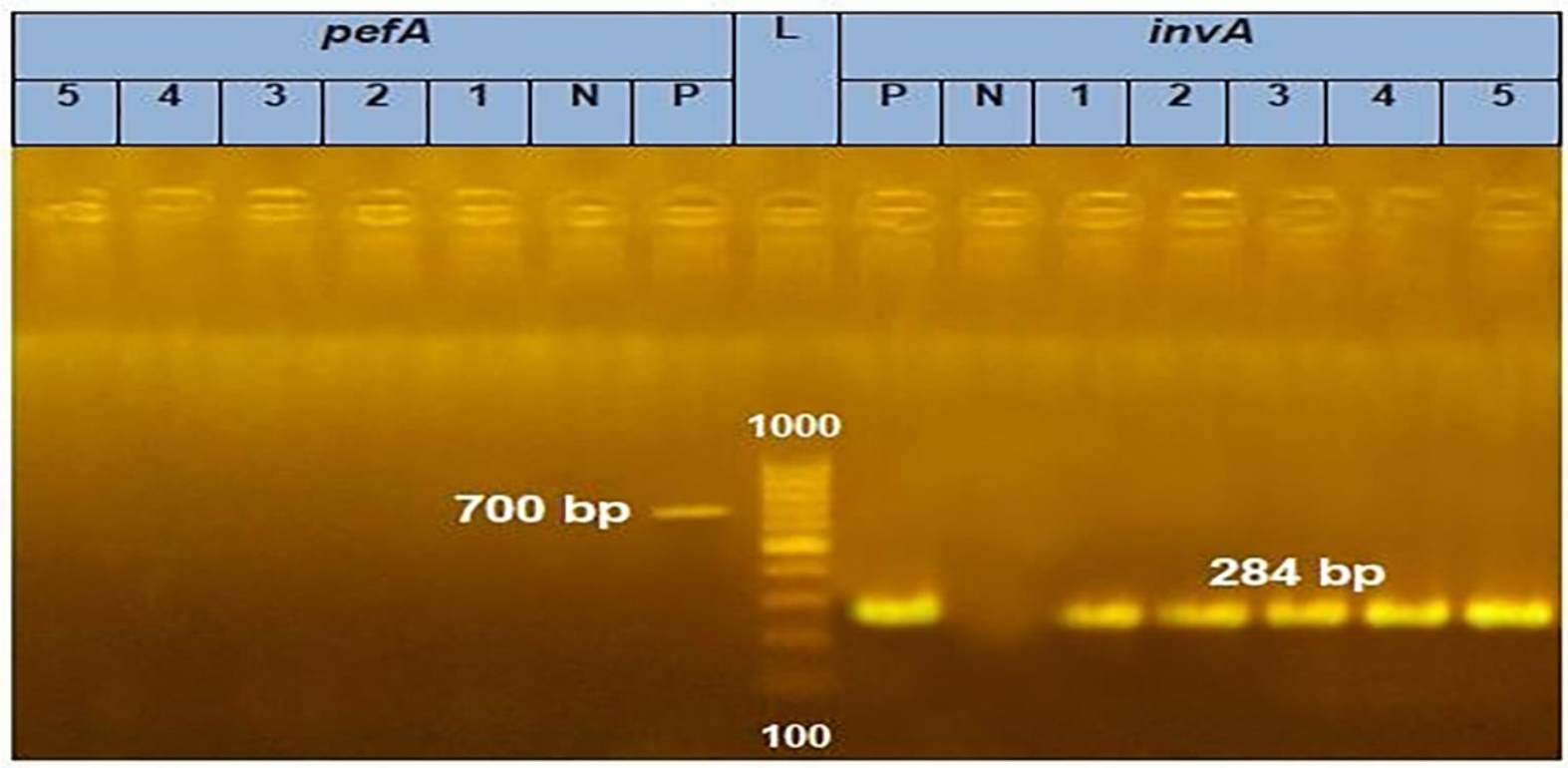

Fig. 1. PCR amplification of the pefA gene at $700 \mathrm{bp}$ and the invA gene at 284bp fragments. Lanes $1-5$ showed positive and negative amplifications. $\mathbf{P}=$ Positive control; $\mathbf{N}=$ negative control; $\mathbf{L}=100-b p$ DNA molecular size ladder. 


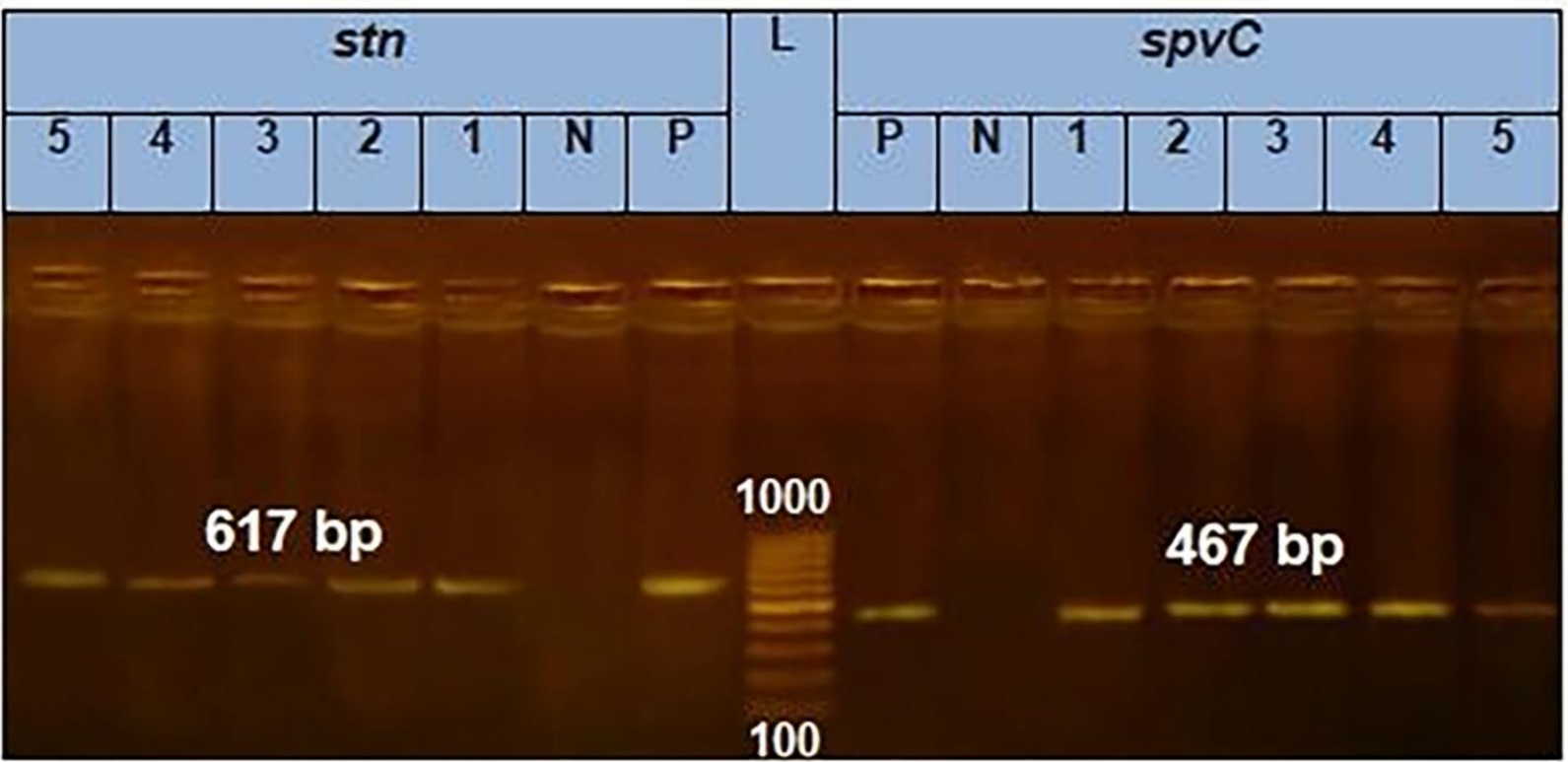

Fig. 2. PCR amplification of the stn gene at $617 \mathrm{bp}$ and the $s p v C$ gene at $467 \mathrm{bp}$ fragments. Lanes $1-5$ showed positive amplifications of sth and spvC genes. $\mathbf{P}=$ Positive control; $\mathbf{N}=$ negative control; $\mathbf{L}=100-b p$ DNA molecular size ladder.

\section{Discussion}

Salmonella infection causes extensive mortality in poultry flocks, leading to serious financial and economic losses in poultry production, as well as posing a public health concern (Pedersen et al. 2002). Identification and genotyping of salmonella isolates are important for the epidemiological surveillance and outbreaks investigation (Hassan et al. 2018).

In the present study, 10 Salmonella spp. were isolated from the 140 samples of internal organs of broiler chickens manifested respiratory signs and/or gastrointestinal problems with a prevalence rate 7.14\%. This result was similar to Sedeik et al. ( 2019) who found that the prevalence of salmonella was $7.5 \%$ in diseased and freshly dead broiler chickens collected from different farms in El-Gharbia, ElBehera, Kafr-Elshikh, Alexandria and MarsaMatrouh Provinces. Also, nearly similar findings; $7.8 \%$ and $7.7 \%$, were recorded in previous studies (Shang et al. 2018; Lassnig et al. 2012). Meanwhile, this result was lower than that detected by Temelli et al. (2012); 30\% and Islam et al. (2014); 49.91\%.

The predominant serovars differ from one geographic area to another. Serotyping of all salmonella isolates revealed that all isolates belonged to $S$. enterica subsp. enterica and 3 serotypes were identified. $S$. kentucky (40\%) followed by both S. blegdam and S. virchow (30\% for each). These results run parallel to that obtained by Djeffal et al. (2018) who detected $S$. kentucky at rate of $49 \%$ and lower than Hegazy (2002) who detected S. kentucky at rates of $62.2 \%$. Also Fagbamila et al. (2017) found that S. kentucky was the dominant serovar isolated from chicken.

Antimicrobial therapy is one of the primary control measures for reducing the morbidity and mortality caused by infectious bacterial diseases. They also used as growth promoters at sub-therapeutic doses for maintaining health and productivity of birds thus reduce the great economic losses in the poultry industry (Bogomazova et al. 2020; Radwan et al. 2020). Due to the similarity of animal and human antimicrobial agents, there is a high risk for developing MDR strains, thus, they must be properly used in veterinary medicine (Seifi et al. 2015; Khaltabadi Farahani et al. 2018).

In the current study, all salmonella isolates $(n=10)$ were tested for their antimicrobial susceptibility for different antimicrobial drugs for detection of the appropriate drug for treatment as well as for detection of the MDR isolates for further analyses. Results illustrated in Table (4) revealed that salmonella isolates were mostly resistant to most of the antimicrobials used while they showed high sensitivity to fosfomycin and nitrofurantoin only. 
The current results run hand to hand with those recorded by Radwan et al. (2016) who reported high sensitivity against fosfomycin (75\%). Meanwhile, $58.3 \%$ of isolates were resistant to amoxicillincalvulanic. Moreover, Radwan et al. (2018) recorded complete resistance to trimethoprim-sulphamethoxazol. Also, Hassan et al. (2018) reported high resistance to sulphamethoxazole-trimethoprime (76.9\%) meanwhile high sensitivities were observed to gentamycin $(73.1 \%)$.

The result of MDR Salmonella isolates as $100 \%$ was similar to that detected by Radwan et al. (2018); $100 \%$ and nearly similar to those detected by Donado-Godoy (2010); 98\%, Radwan et al. (2016); 75\%, and Hassan et al. (2018); $92.3 \%$. A lower percentage was detected by Fallah et al. (2013); $34.1 \%$. MDR mechanisms in Salmonella isolates were associated with mobile genetic elements (plasmids, integrons or transposons) that can be transferred among bacteria and enhance the spreading of these resistance genes in the bacteria (Radwan et al. 2020). Also Dhanani et al. (2015) reported that all salmonella isolates of broiler chicken carried multidrug efflux pump systems regardless of their antibiotic susceptibility profile. So there is an increasing risk of spread of antimicrobial-resistant Salmonella to public health (Youn et al. 2017).

Salmonellae are mostly invasive bacteria having various systems for penetration and interaction with the epithelial mucosa for systemic invasion (Galan 2001). Indeed, a multiple virulence-associated genetic regions termed salmonella pathogenicity islands (SPI) which encoding multiple virulence factors and essential for salmonella pathogenicity have been identified. The most two important SPIs are SPI-1 and SPI-2 which encode structural proteins that form needle-like complexes allowing the insertion of the bacterial proteins inside the host cells modulating both the cellular functions and immune pathways (Galan 2001). There are at least 60 genes related to SPIs; many of such genes are encoded on SPI-1 while the majority is located on the chromosome or on large virulence-associated plasmids (Hassan et al. 2018). SPI-1 is responsible for the invasion of epithelial cells and macrophage apoptosis induction (Rhen and Dorman 2005). The invA is located in SPI-1 (Amavisit et al. 2003). Salmonellae lacking SPI-1 have significantly lower invasiveness ability than invA-positive strain ( $\mathbf{L i}$ et al. 2011).
Salmonella invA gene was considered one of the most popular PCR target sequences and its amplification was recognized as an international standard for detection of salmonella and considered as target genes for the detection of salmonellae at the genus level and it is important in its pathogenesis (Radwan et al. 2016). The inv $\mathrm{A}$ gene encodes a specific protein present in the bacterial inner membrane which is essential for invasion of the host epithelial cells (Darwin and Miller 1999). In addition, fimbriae are important for salmonella pathogenicity as they promote the salmonella attachment to epithelial cells. Pef fimbria is encoded by the pef operon (Murugkar et al. 2003; Ammar et al. 2016). Other chromosomal gene like stn, encoding enterotoxin production has been shown to be a causative agent of diarrhea also $s t n$ is involved in the regulation of bacterial cell membrane integrity (Huehn et al. 2010; Osman et al. 2010; Thung et al. 2018). In addition, $s p v \mathrm{C}$ is located on a self-transmissible virulence plasmid, which facilitates the systemic spread of Salmonella, highlighting the potential high virulence of the salmonella isolates and contributes to the colonization of deeper tissues among other functions (Abd El-Aziz 2018; Rozwandowicz et al. 2018).

In the current work, PCR was also applied on 5 MDR Salmonella to detect 4 genes. The results illustrated in Table (5) and Figs. $(1,2)$ revealed that all the tested Salmonella isolates harbored invA, stn and spvC genes meanwhile no isolates harbored pefA gene.

Concerning invA gene finding, similar results were obtained in other studies in Egypt (Radwan et al. 2016; Hassan et al. 2018; Awad et al. 2020) as well as other studies worldwide (Amini et al. 2010 in Iran, Campioni et al. 2012 in Brazil; Mphuthi et al. 2020 in South Africa).

Also stn and $s p v \mathrm{C}$ virulence genes results were similar to those reported by Ahmed et al. (2016); ElSheikh et al. (2019); Awad et al. (2020). Meanwhile, Diarrassouba et al. (2007) recorded lower rates especially $s p v \mathrm{C}$ gene which was detected in $42 \%$ of the isolates while Ammar et al. (2016) reported that only $5.88 \%$ of tested isolates were $s p v \mathrm{C}$ positive. Also Khaltabadi Farahani et al. (2018) reported $s p v \mathrm{C}$ as $37.6 \%$.

In the current study pefA gene was completely absent in the tested isolates. This was similar to the result obtained by Elkenany et al. (2019) and Elhariri et al. (2020) in which pefA gene was not detected. But 
there were different results recorded in previous studies (Retamal et al. 2015; 93\%; Ahmed et al. 2016; 6.7\%).

\section{Conclusion}

The presence of multidrug resistance pathogens occur due to the misuse of the antibiotics. In this study, all salmonella isolates were MDR. Furthermore, different virulence associated genes were analyzed using multiplex-PCR.

\section{Authors Contributions}

All authors contributed equally to study design methodology, interpretation of result and preparing of the manuscript.

\section{Conflict of interest}

The authors declare no conflict of interest.

\section{References}

Abd El-Aziz OAA (2018). Phenotypic and genotypic characterization of salmonellae isolated from local breeds breeder chickens and their progeny and their effect on production. M.V.Sc degree, Bacteriology, Mycology and Immunology, Faculty of Veterinary Medicine, Beni-Suef University.

Ahmed HA, El-Hofy FI, Shafik SM, Abdelrahman MA, Elsaid GA (2016). Characterization of virulence-associated genes, antimicrobial resistance genes, and class 1 integrons in Salmonella enterica serovar Typhimurium isolates from chicken meat and humans in Egypt. Foodborne Pathogens and Disease, 13(6): 281-288.

Amavisit P, Lightfoot D, Browning GF, Markham PF (2003). Variation between pathogenic serovars within Salmonella pathogenicity islands. J. Bacteriol., 185: 3624-3635.

Amini K, Salehi TZ, Nikbakht G, Ranjbar R, Amini J and Ashrafganjooei SB (2010). Molecular detection of invA and $\mathrm{spv}$ virulence genes in Salmonella Enteritidis isolated from human and animals in Iran. Afr. J. Microbiol. Res., 4(21):2202-2210.

Ammar AM, Mohamed AA, Abd El-Hamid MI, El-Azzouny MM (2016). Virulence genotypes of clinical Salmonella Serovars from broilers in Egypt. The Journal of Infection in Developing Countries, 10(4): 337-346.

Awad AM, El-Shall NA, Khalil DS, El-Hack A, Mohamed E, Swelum AA, Mahmoud AH, Ebaid H, Komany A, Sammour RH (2020). Incidence, pathotyping, and antibiotic susceptibility of avian pathogenic Escherichia coli among diseased broiler chicks. Pathogens, 9(2): 114.

Barrow PA, Neto OF (2011). Pullorum disease and fowl typhoid-new thoughts on old diseases: A review. Avian Pathol., 40: 11-13.
Bogomazova AN, Gordeeva VD, Krylova EV, Soltynskaya IV, Davydova E E, Ivanova OE, Komarov AA (2020). Mega-plasmid found worldwide confers multiple antimicrobial resistance in Salmonella Infantis of broiler origin in Russia. International Journal of Food Microbiology, 319: 108497.

Campioni F, Bergamini AMM, Falcão JP (2012). Genetic diversity, virulence genes and antimicrobial resistance of Salmonella enteritidis isolated from food and humans over a 24-year period in Brazil. Food Microbiol. 32:254-264.

Clinical and Laboratory Standards Institute (CLSI) (2018). Performance standards for antimicrobial susceptibility testing, 28th Ed. M100-S.

Collee JG, Fraser AG, Marmion BP, simmons A (1996). Practical medical microbiology. 14th Ed., Chuechill, living stone.

Darwin KH, Miller VL (1999). Molecular basis of the interaction of Salmonella with the intestinal mucous. Clin. Microbiol. Rev., 12: 405-428.

Davies J, Davies D (2010). Origins and evolution of antibiotic resistance. Microbiol Mol Biol Rev., 74(3):417-33.

Dhanani AS, Block G, Dewar K, Forgetta V, Topp E, Beiko RG, Diarra MS (2015). Genomic comparison of nontyphoidal Salmonella enterica serovars Typhimurium, Enteritidis, Heidelberg, Hadar and Kentucky isolates from broiler chickens. PLoS One, 10(6): 0128773.

Diarrassouba F, Diarra MS, Bach S, Delaquis P, Pritchard J, Topp E, Skura BJ (2007). Antibiotic resistance and virulence genes in commensal Escherichia coli and Salmonella isolates from commercial broiler chicken farms. J Food Prot., 70: 1316-27

Djeffal S, Mamache B, Elgroud R, Hireche S, Bouaziz 0 . (2018). Prevalence and risk factors for Salmonella spp. contamination in broiler chicken farms and slaughterhouses in the northeast of Algeria. Vet World, 11(8): 1102.

Donado-Godoy P (2010). Prevalence, resistance patterns and risk factors for antimicrobial resistance in poultry farms and retail chicken meat in Colombia and molecular characterization of Salmonella Paratyphi B and Salmonella Heidelberg. Ph. D. dissertation. University of California, Davis.

Elhariri M, Elhelw R, Selim S, Ibrahim M, Hamza D, Hamza E (2020). Virulence and antibiotic resistance patterns of extended-spectrum beta-lactamase-producing Salmonella enterica serovar Heidelberg isolated from broiler chickens and poultry workers: A potential hazard. Foodborne Pathogens and Disease, 17(6): 373381.

Elkenany R, Elsayed MM, Zakaria Al, El-Sayed SA-E-S, Rizk MA (2019). Antimicrobial resistance profiles and virulence genotyping of Salmonella enterica serovars 
recovered from broiler chickens and chicken carcasses in Egypt. BMC Vet Res., 15(1): 1-9.

ElSheikh M, Abdeen E, Ammar A (2019). Molecular Detection of Some Virulence Genes of Salmonella Serotypes Isolated From Poultry in Egypt. J Current Vet Res., 1(1): 86-93.

Fagbamila IO, Barco L, Mancin M, Kwaga J, Ngulukun SS, Zavagnin P, Lettini AA, Lorenzetto M, Abdu PA, Kabir J, Umoh J, Ricci A, Muhammad M( 2017). Salmonella serovars and their distribution in Nigerian commercial chicken layer farms. PLoS One, 12: 0173097

Galan JE (2001). Salmonella interactions with host cells: type III secretion at work. Annual Review of Cell and Developmental Biology, 17: 53-86.

Gast RK, Shivaprasad HL, Barrow PA (2003): Salmonella infections. Diseases of poultry, 11: 567-613.

Grimont PAD, Weil FX (2007): Antigentic formulae of the Salmonella serovars. WHO collaborating. Center of Reference and Research on Salmonella, Institute, Pasteur, 1-166.

Haider MG, Hossain MG, Hossain MS, Chowdhury EH, Das PM, Hossain MM (2004). Isolation and characterization of enterobacteria associated with health and disease in sonali chickens. Bangl J Vet Med., 2: 15-21.

Hassan WH, Abed AH, Thabet A, El Nady EAM (2018). Genetic analysis of multidrug resistant Salmonella isolated from broiler chickens. J Vet Med Res., 25 (1): 121-131.

Hegazy AE (2002). Epidemiological studies on Salmonellosis in chickens with special reference to Salmonella Enteritidis. PhD Thesis, Fac Vet Med Alex Univ Egypt.

Huehn S, La Ragione RM, Anjum M, Saunders M, Woodward MJ, Bunge C (2010). Virulotyping and antimicrobial resistance typing of Salmonella enterica serovars relevant to human health in Europe. Foodborne Pathog Dis., 7: 523-535.

Islam MM, Islam MN, Sharifuzzaman FM, Rahman MA, Sharifuzzaman J U, Sarker EH, Shahiduzzaman M, Mostofa M, Sharifuzzaman MM (2014). Isolation and identification of Escherichia coli and Salmonella from poultry litter and feed. Int J Nat Soc Sci., 1(1): 1-7.

Khaltabadi Farahani R, Ehsani P, Ebrahimi-Rad M, Khaledi A (2018). Molecular detection, virulence genes, biofilm formation, and antibiotic resistance of Salmonella enterica serotype enteritidis isolated from poultry and clinical samples. Jundishapur J Microbiol., 11(10).

Lassnig H, Much P, Schliessnig H, Osterreicher E, Kostenzer K, Kornschober C, Koefer J (2012). Prevalence of Salmonella spp. in Austrian broiler flocks in the context of the EU-wide baseline survey 20052006. Berliner Und Munchener Tierarztliche Wochenschrift, 125(3-4): 129-137.

Li YH, Xu XB, Hu QH, Shi XL, Lin YM, Qiu YQ (2011).
Characteristics of Salmonella enterica serovar Senftenberg lacking Salmonella pathogenicity island 1. Zhonghua Yu Fang Yi Xue Za Zhi .Chinese J Preventive Med., 45(10): 899-903.

Rozwandowicz M, Brouwer MSM, Fischer J, Wagenaar JA, Gonzalez-Zorn B, Guerra B (2018).Plasmids carrying antimicrobial resistance genes in EnterobacteriaceaeJ Antimicrob Chemother, 73: 1121-1137.

Magiorakos AP, Srinivasan A, Carey RB, Carmeli Y, Falagas ME, Giske CG (2012). Multidrug-resistant, extensively drug-resistant and pandrug-resistant bacteria: an international expert proposal for interim standard definitions for acquired resistance. Clin Microbiol Infect., 18(3):268-281.

Mphuthi N, Thekisoe OMM, Ramaili T, Syakalima M, Ramatla TA, Taioe MO (2020). Molecular detection of virulence genes in Salmonella spp. isolated from chicken faeces in Mafikeng, South Africa. J South African Vet Assoc., 91(1): 1-7.

Murugkar HV, Rahman H, Dutta PK (2003). Distribution of virulence genes in Salmonella serovars isolated from man and animals. Indian J. Med. Res., 117: 66-70.

Olivera SD, Rodenbusch CR, Ce MC, Rocha SLS, Canal CW (2003). Evaluation of selective and non selectiveenrichment PCR procedures for Salmonella detection. Lett Appl Microbiol., 36: 217-221.

Osman KM, Yousef AM, Aly MM, Radwan MI (2010) Salmonella spp. infection in imported 1-dayold chicks, ducklings, and turkey poults: a public health risk. Foodborne Pathog Dis., 7: 383-390.

Pedersen K, Hansen HC, Jorgensen JC, Borck B (2002). Serovars of Salmonella isolated from Danish turkeys between 1995 and 2000 and their antimicrobial resistance. Vet Rec., 150(15): 471-474.

Phillips I, Casewell M,Cox T, de Groot B, Fiis C, Jones R, Nightingale C, Preston R, Waddell J (2004). Does the use of antibiotics in food animals pose a risk to human health? A critical review of published data. J Antimicrobial Chemotherapy 53: 28-52.

Quinn PJ, Markey BK, Carter ME, Donnelly WJC, Leonard FC, Maguire D. (2002)Veterinary microbiology and microbial diseases. 1st edition, Published Blackwell Science, Hoboken, NJ, 536 pp.

Radwan IA, Abd El-Halim MW, Abed AH (2020). Molecular characterization of antimicrobial resistant Escherichia coli isolated from broiler chickens. J Vet Med Res., 27(2): 128-142

Radwan IA, Abed AH, Abd Al-Wanis SA, Abd El-Aziz GG, ElShemy A (2016). Antibacterial effect of cinnamon and oreganium oils on multidrug resistant Escherichia coli and Salmonellae isolated from broiler chickens. J Egy Vet Med Ass., 76 (2): 169-186.

Retamal P, Fresno M, Dougnac C, Gutierrez S, Gornall V, Vidal R, Vernal R., Pujol M, Barreto M, GonzálezAcuña D, Abalos P (2015). Genetic and phenotypic 
evidence of the Salmonella enterica serotype Enteritidis human-animal interface in Chile. Front Microbiol., 6: 464.

Rhen M, Dorman CJ (2005). Hierarchical gene regulations adapt Salmonella enterica to its host milieus. Int J Med Microbial., 294: 487-502.

Sedeik ME, Nahed A, Awad AM, Elfeky SM, Abd El-Hack ME, Hussein EO S, Alowaimer AN, Swelum AA (2019). Isolation, conventional and molecular characterization of Salmonella spp. from newly hatched broiler chicks. AMB Express, 9(1): 1-6.

Seifi S, Khoshbakht R, Atabak AR (2015). Antibiotic susceptibility, serotyping and pathogenicity evaluation of avian Escherichia coli isolated from broilers in northern Iran. Bulgarian J Vet Med., 18(2).

Shang K, Wei B, Kang M (2018). Distribution and dissemination of antimicrobial-resistant Salmonella in broiler farms with or without enrofloxacin use. BMC Vet Res., 14(1): 1-14.

Su LH, Chiu CH, Chu C, Ou JT (2004). Antimicrobial resistance in nontyphoid Salmonella serotypes: a global challenge. Clin Infect Dis., 39: 546-551.

Thung TY, Radu S, Mahyudin NA, Rukayadi Y, Zakaria Z, Mazlan N (2018). Prevalence, virulence genes and antimicrobial resistance profiles of Salmonella serovars from retail beef in Selangor, Malaysia. Front Microbiol., 8: 2697.

Temelli S, Eyigor A, Carli KT (2012). Salmonella detection in poultry meat and meat products by the Vitek immunodiagnostic assay system easy Salmonella method, a LightCycler polymerase chain reaction system, and the International Organization for Standardization method 6579. Poultry Sci., 91(3): 724731.
Vinueza-Burgos C, Baquero M, Medina J, De Zutter L (2019). Occurrence, genotypes and antimicrobial susceptibility of Salmonella collected from the broiler production chain within an integrated poultry company. Int J Food Microbiol., 299: 1-7.

Vose D, Koupeev T, Mintiens KA (2011). Quantitative microbiological risk assessment of Salmonella spp. in broiler (Gallus gallus) meat production. EFSA Support. Publ., 8, 183E.

World Health Organization (WHO) (2016). Interventions for the control of non-typhoidal Salmonella spp. Thorgeir L. (Ed.), Beef and Pork: Meeting Report and Systematic Review, Microbiological Risk Assessment Series No. 30, Rome, Italy pp. 1-10

Youn SY, Jeong OM, Choi BK, Jung SC, Kang MS (2017). Comparison of the antimicrobial and sanitizer resistance of Salmonella isolates from chicken slaughter processes in Korea. J Food Sci., 82(3):711-7.

Zou M, Keelaraand S, Thakur S (2012). Molecular characterization of Salmonella enterica serotype Enteritidis isolates from humans by antimicrobial resistance, virulence genes and pulsed-field gel electrophoresis. Foodborne Path Dis., 9: 232-238.

How to cite this article: Hassan WH, Hassan HS, Hassan WMM, Shany SAS, Osman GSI. Identification and characterization of Salmonella species isolated from broiler chickens. J Vet Med Res., 2021; 28(1): 21-29. https://doi.org/10.21608/jvmr.2021.89244.1041 